\title{
Circulating nucleic acids in plasma or serum (CNAPS) as prognostic and predictive markers in patients with solid neoplasias
}

\author{
Georg Goebel ${ }^{\mathrm{a}}$, Marion Zitt ${ }^{\mathrm{b}}$, Matthias Zitt ${ }^{\mathrm{b}}$ and Hannes M. Müller ${ }^{\mathrm{b}, *}$ \\ ${ }^{\mathrm{a}}$ Department of Medical Statistics, Informatics and Health Economics, Innsbruck Medical University, A-6020 \\ Innsbruck, Austria \\ ${ }^{\mathrm{b}}$ Department of General and Transplant Surgery, Innsbruck Medical University, A-6020 Innsbruck, Austria
}

\begin{abstract}
It is now widely accepted that there is a need for the development of molecular markers of cancer that can be used for clinical prognostication and monitoring. Approximately a decade ago tumor-derived circulating nucleic acids in the plasma or serum (CNAPS) of cancer patients were introduced as a noninvasive tool for cancer detection. This review focuses on the various types of CNAPS of patients with solid neoplasias (genetic alterations in circulating DNA, microsatellites, methylated DNA, viral DNA, nucleosomes, mitochondrial DNA and cell-free mRNA) and their putative potential as prognostic or predictive parameter or even as a tool for therapy monitoring during follow-up. Additionally, this review aims to point out the difference between a prognostic and a predictive factor in patient bloodstream. However, with rapid technical improvement and well-designed studies we conclude that the next years will see CNAPS analysis integrated in the prognostication and monitoring of cancer patients, thus producing more specific treatment regimens for patients with various stages of neoplastic disease and ultimately longer survival and better quality of life.
\end{abstract}

Keywords: Circulating nucleic acids in plasma or serum, CNAPS, serum, plasma, neoplasia, methylated DNA, nucleosomes, mitochondrial DNA, cell-free mRNA, viral DNA, microsatellites, genetic alterations, prognosis, monitoring

\section{Introduction}

In 1947, a few years before Watson and Crick elucidated the double-helical structure of DNA, Mandel and Métais [1] reported for the first time circulating nucleic acids in the bloodstream. Using a perchloric acid precipitation method, they reported that mainly RNA, but also DNA, can be found in the plasma of healthy and diseased persons. Despite the innovative nature of this work, little attention was drawn to these findings until

* Corresponding author: Hannes M. Müller, MD, Department of General and Transplant Surgery, Innsbruck Medical University, A6020 Innsbruck, Austria. Tel.: +43 512504 22555; Fax: +43 512 504 28519; E-mail: hannes.mueller@uibk.ac.at.
1966, when Tan and coworkers [2] demonstrated the presence of DNA in the serum and plasma of patients afflicted with systemic lupus erythematosus. The presence of DNA and RNA in plasma of cancer patients has been recognized since the 1970s [3,4], but the first evidence supporting the tumor origin of plasma DNA was provided in the late eighties [5]. The final proof that tumors shed DNA into circulation came from Sorenson and coworkers [6] reporting the detection of tumorderived oncogene mutation ( $K$-ras) in pancreatic cancer, and Vasioukhin and coworkers [7] reporting $N$-ras mutations in the plasma of patients with myelodyspalstic syndrome and acute myelogenous leukemia.

Additionally, it turned out that in control subjects, the mean concentration of soluble DNA in plasma was 
estimated at $14-18 \mathrm{ng} / \mathrm{ml}$, whereas in patients with various types of neoplasias, the mean concentration is 180 $318 \mathrm{ng} / \mathrm{ml}[3,8,9]$. The increase in serum DNA in cancer patients is mostly attributable to freely circulating tumor DNA [8]. On the basis of these pioneering studies, a new field of tumor marker research has emerged, especially focusing on serum/plasma which seems to be a compartment enriched in tumor-specific DNA and RNA. This compartment is currently the focus of much effort to detect either premalignant changes, cancer or relapse of disease. This review focuses on published studies dealing with the prognostic or even predictive value of tumor-specific circulating nucleic acids in plasma or serum (CNAPS) of patients with solid neoplasias.

\section{Various types of circulating nucleic acids in cancer patients}

The majority of reports evaluating a prognostic test in solid tumors face one major obstacle: the need for invasive procedures to obtain adequate testing material. Therefore, the easy accessibility of CNAPS opens up a new field for prognostic testing and therapy monitoring during follow-up. Overall, average DNA levels are significantly elevated in cancer patients as compared to healthy controls, irrespective of the use of serum or plasma, but it turned out that absolute DNA levels were lower in studies using plasma than in those analyzing serum samples [10-12].

Most studies on CNAPS in cancer patients focused on genetic alterations. During recent years mutations of the ras oncogene family have been very frequently described in circulating DNA (for review see [13,14]). Such mutations occur early in the development of cancer, are highly specific for cancer, and have a wellcharacterized site and therefore represent a possible marker for serologic cancer diagnosis. Approximately one-fourth of patients with colorectal cancer and onehalf of those with pancreatic cancer have mutant $K$-ras sequences detectable in plasma [6,15-17]. Compared to the analysis of ras, the detection of p53 alterations is especially laborious owing to the potential presence of mutations along several exons. Despite this fact, numerous groups have searched for $p 53$ mutations in serum/plasma, probably due to the prevalence of $p 53$ alterations in most malignancies. P53 mutations were reported in the plasma of patients with hepatocellular carcinoma [18,19], breast cancer [20,21], lung cancer [21] and colorectal cancer [22]. Most remaining studies have analyzed p53 mutations in plasma and serum together with other genetic or epigenetic alterations [23-28]. Similar to genetic alterations of $p 53$ and ras oncogene, mutated adenomatous polyposis coli (APC) gene sequences can occasionally be detected in the plasma of patients with sporadic colorectal cancer [23,29] and erbB-2 amplifications in those with esophageal cancer [30].

Microsatellites are repetitive DNA sequences, ranging in size from $2 \mathrm{bp}$ to $6 \mathrm{bp}$, that form variable-length stretches of DNA. With appropriate primers it is possible to amplify DNA fragments that can be used as microsatellite markers, and with a panel of such markers, tumors can be profiled. Microsatellite alterations are detectable in serum/plasma of patients with lung cancer [31-33], head and neck cancer [34], breast cancer [35], melanoma [36,37], renal cell carcinoma [38].

Changes in the status of DNA methylation, known as epigenetic alterations, are among the most common molecular alterations in human neoplasia [39-41]. An increasing number of studies have reported the presence of methylated DNA in serum/plasma and other body fluids of patients with various types of malignancy and the absence of methylated DNA in normal control patients (for review see [42]). Therefore, epigenetic alteration represents important serologic markers for risk assessment and even for therapy monitoring during follow-up of cancer patients.

Additional compounds recovered from blood have been tested for a potential prognostic application in cancer. These include viral DNA, nucleosomes, mitochondrial DNA, and mRNA.

Viruses such as human papillomavirus (HPV) and Epstein-Barr virus (EBV) are etiological factors in various malignancies, therefore having the potential to be used as molecular markers for several neoplastic diseases. Associations exist for EBV and Hodgkin's disease, Burkitt's lymphoma, nasopharyngeal carcinoma (NPC) and for HPV with head and neck and cervical cancers (for review see [13,14]). During the past years it turned out that it is possible to use cell-free EBV DNA in plasma of NPC patients to monitor the response to a given treatment or to evaluate the prognosis of these patients. The clinical value relates to the observation that those in whom the concentrations do not reach zero (or at least decrease to a low value) subsequently relapse $[43,44]$. Additionally, one can find a poorer prognosis in those patients showing high levels of EBV DNA [45]. As mentioned above, several other malignancies are associated with EBV infection, like lymphomas, particularly Hodgkin's disease. 
EBV DNA has been detected in both adult and pediatric Hodgkin's patients [46,47]. Additionally, it has been suggested that different concentrations of EBV DNA were likely to be of prognostic significance [46, 48,49]. HPV infection is an etiological factor in cervical carcinoma. Recently, detection of HPV DNA in serum/plasma of patients with cervical cancer and HPV-associated head and neck squamous cell carcinoma has been described [50-53]. Very recently, we were able to demonstrate that serum HPV DNA seems to reflect biological activity of cervical cancer and, furthermore, that serum HPV DNA might be a useful additional marker for early detection of recurrence in cervical cancer patients [54].

Nucleosomes originate from endonuclease cleavage of chromatin during apoptotic cell death, and are composed of a histone octamer core wrapped with $180 \mathrm{bp}-$ $200 \mathrm{bp}$ DNA. It is now widely accepted that nucleosomes, and in particular mononucleosomes, are the form in which cell-free DNA circulates in the bloodstream (for review see [14]). Kuroi and coworkers reported a significant increase in nucleosome levels in breast cancer patients as compared with healthy controls. Otherwise, no correlation was detected with the most important clinicopathological features or prognosis of breast cancer patients [55]. Very recently, Holdenrieder and coworkers found circulating nucleosomes to represent independent predictors of therapy response in patients with stage III and IV NSCLC undergoing chemotherapy [56].

Each human cell contains several hundred copies of mitochondrial DNA (mtDNA) that encodes respiratory chain subunits, tRNAs, and rRNAs. In recent years, several mutations have been described in patients with colorectal cancer, bladder cancer, lung cancer, and head and neck cancer $[14,57]$. Recently, mtDNA mutations have been reported in the plasma of patients with early prostate cancer [58] and in the serum/plasma of patients with hepatocellular carcinoma [59,60], as well as in the serum of CRC patients [61]. Additionally, cellfree $m R N A$ can also be detected in serum or plasma, a fact that gives rise to the suggestion that expression profiling can be performed in patient bloodstream. In patients with cancer, RNA may derive from tumorassociated viruses (e.g. DNA viruses that have an RNA genome as an obligatory part of their replicative strategy) or directly from the tumor (for review see [13, 14]). Recently, it was reported that tumor-derived tyrosinase mRNA was detected in four of six patients with metastatic melanoma but not in healthy controls [62]. The authors were able to rule out the contamination of serum with circulating tumor cells, which suggests the cell-free origin of the tyrosinase transcript. A similar detection rate for tyrosinase mRNA was reported by a second work [63]. Additionally, telomerase mRNA has been detected in serum/plasma of patients with various types of neoplasia, including breast cancer [64] or CRC $[65,66]$. It must be mentioned that there are additional candidate mRNA markers for early detection and therapy monitoring, but further data are needed to assess their real utility.

\section{The putative origin of CNAPS}

Although it is evident that DNA or RNA circulates freely in the bloodstream of healthy controls or even in cancer patients, the source remains enigmatic. It can be presumed that circulating DNA in healthy subjects derives from lymphocytes or other nucleated cells. Yet, it is not known why cancer patients have such large quantities of plasma DNA, nor where this genetic material derives from. However, it is now widely accepted that a substantial proportion of circulating DNA in cancer patients derives from tumor cells (for review see [67]). The most common hypothesis concerning the origin of circulating tumor-specific DNA, namely the lysis of circulating cancer cells or micrometastasis shed by the tumor, has turned out to be wrong, because there are not enough circulating cells to justify the amount of DNA found in the bloodstream. It thus appears that circulating tumor-specific DNA could be due either to DNA leakage resulting from tumor necrosis or apoptosis or to a new mechanism of active release (for review see [67]). Additionally, not much is yet known about the methylation pattern of several genes in normal white blood cells or even endothelial cells which may also serve as a source of cell-free DNA detected in the bloodstream. Another possible source of methylated DNA may be normal tissues which show increasing methylation values during aging [68-70].

An alternative - and likewise attractive - hypothesis is that circulating altered DNA per se may cause denovo development of tumor cells in organs known to harbor cancer metastases. This hypothesis is supported by the fact that a horizontal transfer of circulating tumor DNA into tissues has been demonstrated in animal experiments, which raises questions on the possible functional relevance of this so-called genometastasis, as opposed to conventional cellular metastatic spread [71]. Additionally, this alternative hypothesis is supported by the fact that methylated oligonucleotides in vitro 
as well as in vivo are able to regulate gene expression in hepatocellular cancer [72]. Hypothetically, under the assumption that horizontal transfer of tumor DNA sequences has a transforming potential [73,74], stem cells in distant organ tissues would constitute possible targets for uptake.

Prognosis in patients with newly diagnosed neoplasia is determined primarily by the local spread of the tumor and by the presence or absence of metastases in draining axillary lymph nodes. Nevertheless, the lifethreatening event in cancer is not lymph node metastasis per se, but hematogenous metastases which mainly affect bone, liver, lung and brain. Therefore, considering the possible mechanism of genometastasis it seems very promising to use CNAPS to develop a prognostic or even predictive test that is sensitive for hematogenous metastases and could be performed on pretherapeutic serum and plasma or even on serum/plasma samples during follow-up.

\section{An alternative means of epigenetic prognostic/predictive marker evaluation}

As mentioned above, numerous studies have demonstrated the presence of methylated DNA in serum/ plasma of patients with various types of malignancy, and the absence of methylated DNA in normal control patients (for review see [42]), although the source of this tumor-specific methylated DNA remains enigmatic. Despite the many unsolved questions, circulating DNA methylation changes represent one of the most promising tools for risk assessment in cancer patients. Nevertheless, it is not yet clear how to proceed to choose the most promising prognostic or predictive DNA methylation markers out of a long list of candidate genes known to be hypermethylated in neoplasia. One possible means of coping with this problem is to focus first on neoplastic tissue specimens and determine those genes that are highly methylated in the tumor of interest. Afterwards one has to search for these methylated genes in corresponding serum or plasma specimens and if methylation changes can be detected therein, their prognostic and predictive value can then be evaluated. This form of methylation marker evaluation can pose some obstacles: the source of the circulating DNA remains enigmatic (see above); not much is known about methylation changes in white blood cells or endothelial cells; it is not yet clear whether a continuous association exists between the methylation status in serum samples and in corresponding tissue speci- mens; aging may also influence the methylation status, not only in neoplastic, but also in normal tissue [6870]. Furthermore, it must be mentioned that prognosis in patients with newly diagnosed cancer is determined primarily by the most life-threatening event in cancer, namely hematogenous metastases which mainly affect bone, liver, lung and brain. Additionally, the hypothesis of genometastasis (described above) suggesting that circulating altered DNA per se may cause de-novo development of tumor cells in organs known to harbor cancer metastases, must be kept in mind. In order to develop a prognostic test that is sensitive for hematogenous metastases investigating directly the compartment containing circulating DNA, we followed a new way for evaluating the most promising DNA methylation marker out of a long list of candidate genes. We used a so-called gene evaluation set looking only at serum samples of advanced cancer patients, normal controls and pre-treatment sera of cancer patients [75]: This gene evaluation set consisted of patients with recurrent disease ( $n=10$; sera obtained at diagnosis of metastasis in the bone, lung, brain or liver) and pretherapeutic sera of recently diagnosed primary breast cancer patients $(n=26)$ and normal controls $(n=10$; all underwent a core biopsy and were confirmed to have benign disease of the breast). Because levels of circulating DNA in metastasized patients are known to be higher [3] and because the loss of genetic heterogeneity of disseminated tumor cells with the emergence of clinically evident metastasis was recently reported [76], we firstly investigated 39 genes in ten sera of metastasized patients to determine the overall prevalence of methylation changes in breast cancer. The 33 genes positive in the sera of the metastasized patients were further evaluated in an independent sample set of pretherapeutic sera of 26 patients with primary breast cancer and ten healthy controls. The most appropriate genes for our further analyses were determined to be those that met one of the following criteria: (i) unmethylated in serum samples from healthy controls and $>10 \%$ methylated in serum samples from primary breast cancer patients, or (ii) $\leqslant 10 \%$ methylated in serum samples from healthy controls and $>20 \%$ methylated in serum samples from primary breast cancer patients. A total of five genes, namely ESR $1, A P C, H S D 17 B 4, H I C l$ and RASSF 1A, met at least one of these criteria. Finally, we were able to demonstrate that our alternative means of marker evaluation is very useful, because two of the determined genes (APC, RASSFIA) turned out to be independent prognostic markers in breast cancer patients. Additionally, when looking solely at serum samples 
of cancer patients we identified $M Y O D 1, C D H 1$ and $\mathrm{CDH} 13$ as being of prognostic value in cervical cancer patients [77-79], which may also indicate some kind of hematogenous metastasis. Irrespective of the mechanistic role of methylated DNA with regards to metastasis in cancer patients, these epigenetic changes in serum have several advantages as indicators of poor prognosis as compared to currently used or studied prognostic parameters: DNA in serum is stable, easy to obtain and can be analyzed with a high-throughput method like MethyLight [77].

One may speculate that this alternative approach can also be used to evaluate possible candidates of other CNAPS, especially if stored serum or plasma samples exist without available corresponding tissue samples.

\section{Prognostic and predictive markers - A big difference}

Over the years, substantial efforts have been made to subdivide patient populations into groups that behave differently, so that therapy can be applied more efficiently. Indeed, the diagnosis of a neoplastic disease itself divides the general population into those with it and those without it. Separation of these two groups is crude, and estimation of prediction of outcome based solely on the diagnosis of a neoplastic disease is very poor. Consequently, doctors began to observe that outcomes were related to clinicopathological features of neoplastic disease, e.g. tumor size, presence or absence of pathologically involved lymph nodes or different grade of tumor tissue. These efforts led to what is now commonly known as the "TNM staging system". The TNM staging system only partially separates patients into subgroups with different biological behaviors and was developed in the era prior to widespread application of adjuvant systemic therapy. Therefore, the TNM staging system was designed to determine patients for whom local therapy (surgery, radiation) was inappropriate and to predict the risk of relapse and death for those patients treated with such modalities. The identification of substantial benefit from various types of adjuvant systemic therapy (chemotherapy, hormone therapy) has provided an opportunity to select specific regimens that might be applied in the individual patient. Therefore, in addition to so-called "prognostic factors", which predict the risk of relapse and death in the absence of systemic therapy, a variety of putative "predictive factors" have been proposed that might predict how well a specific therapeutic agent will work [80, 81].

In the context of the explosion of molecular biology over the past decades a series of molecular prognostic factors have been studied. Despite the hundreds of putative molecular markers that have been reported, only very few have actually gained widespread clinical acceptance. In part, this frustrating lack of progress is a function of the biological diversity of neoplastic disease. Furthermore, much of the confusion and controversy in this field stems from poorly designed and analyzed studies $[80,81]$. Over the past decades several studies have suggested a great potential for CNAPS as markers for neoplastic disease in several body fluids. Furthermore, it is also possible that CNAPS have great potential as prognostic or even predictive markers in neoplastic disease (for review see $[13,14,42,82]$. Because the distinction between prognostic and predictive factors can critically affect the results of a clinical or laboratory investigation [80,81], we want to point out the importance of paying more attention to this fact when introducing CNAPS into clinical routine as prognostic and predictive markers.

Prognostic factors are associated with either the metastatic and/or growth rate potential of the primary tumor and are related to patient outcome independent of the treatment they receive [80,81]. Predictive factors are associated with relative sensitivity and/or resistance to specific therapeutic agents. Of note, the same factor may be both prognostic and predictive. From the statistical viewpoint the type of therapy must in this case be considered a confounding variable in a multivariate model (e.g. Cox regression model). A purely prognostic factor separates groups of cancer patients, independent of therapy (Fig. 1a and 1b). In the case of an ideal predictive factor the presence of a specific treatment for which the factor predicts sensitivity or resistance, the patients's outcomes are very different depending on tumor marker results. A mixed prognostic/predictive factor separates groups to some degree in the absence of the relevant therapy, but much more so in the presence of the specific therapy (Fig. 1c and 1d). For example, in the case of breast cancer, metastatic involvement of axillary lymph nodes is generally considered a "purely prognostic" factor, whereas the estrogen receptor (ER) protein content of the primary tumor may play both a prognostic and a predictive role [80,81]. It is well established that breast cancer patients benefit from hormone therapies in the adjuvant or metastatic setting if they have hormone receptor-positive tumors. Although the predictive strength of ER is not absolute, patients 


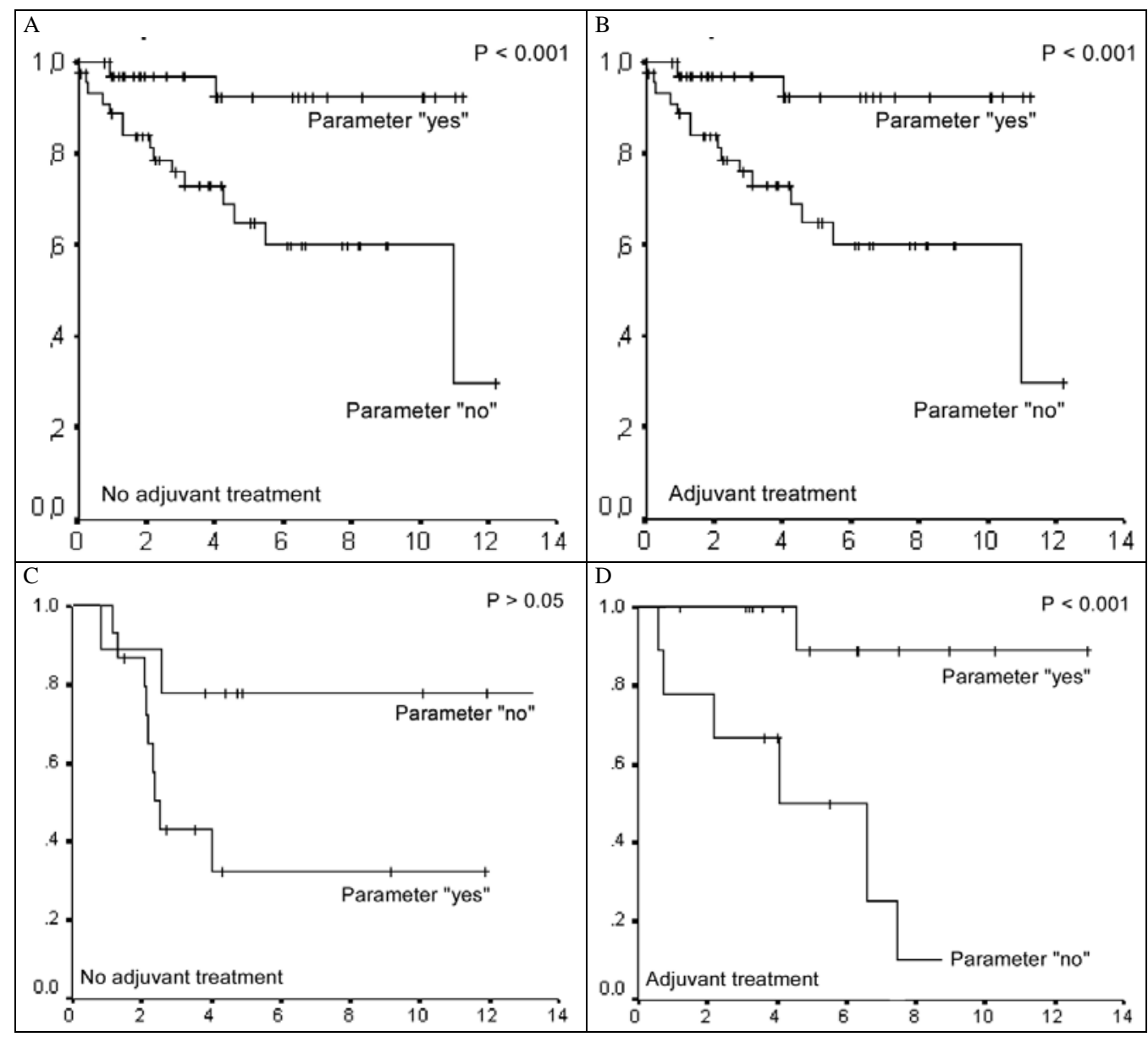

Fig. 1. A and B show typical Kaplan Meier curves for a purely prognostic parameter. The stratification factor "therapy" does not show differences between patients without and with adjuvant treatment. C and D show examples of Kaplan Meier curves, where a predictive parameter confounds the outcome of patients without and with adjuvant treatment.

with ER-poor tumors are much less likely to benefit from hormone therapy than are those whose tumors are ER-rich. Additionally, it has been observed that ERpoor breast cancers appear to grow more rapidly and behave more aggressively than ER-rich tumors. Thus, it was proposed that ER content might also be prognostic $[80,81]$. Beside the often unappreciated issue of prognosis and prediction, many other issues further complicate the interpretation of studies with regard to prognosis. Most, studies are retrospective, include only small numbers of patients and do not control for other confounding prognostic variables. Additionally, differing lengths of follow-up and different endpoints (response, disease-free survival, overall survival, relative risk of relapse or death) contribute to misinterpretation of prognostic studies. Therefore, the ideal study should be prospectively designed for a defined popu- lation of patients in order to address the clinical utility of the prognostic factor using predetermined methods and cutoffs. In an effort to avoid the confounding effect of treatment, only patients who do not receive systemic therapy should be studied. In addition, studies should report the relative risk of recurrence and/or mortality associated with a specific factor, thus allowing the strength of various prognostic factors to be compared $[80,81]$. On the one hand, we want to emphasize the importance of a well-designed (prospective) study, but we also feel it is very important to initially use retrospective analysis of serum or plasma samples to pick out promising markers for further analysis. Within this review we discuss a new possible means of marker evaluation using a retrospective study design (see above). At bottom, every putative prognostic parameter has to be tested in a prospective, multicenter study before it can be introduced in clinical routine. 


\section{Prognostic and predictive potential of various CNAPS}

\subsection{Genetic mutations}

The first studies dealing with tumor-specific CNAPS reported mutations of various genes to have the potential to serve as tumor markers in patient bloodstream. With regard to the prognostic or even predictive value of genetic mutations in plasma or serum of cancer patients, only a few reports can be found:

Concerning pancreatic cancer patients a relation to tumor size, stage, and relapse risk was noted, and plasma K-ras mutations were shown to be independent prognostic factors for survival $[83,84]$. Yamada and coworkers reported some kind of predictive value of K-ras mutations in plasma: treatment normally resulted in a disappearance of K-ras mutations in plasma, whereas those patients persistently positive for K-ras mutation in plasma showed early recurrence or progressive disease [83]. Furthermore, K-ras mutations were reported to have prognostic potential in serum of nonsmall cell lung cancer (NSCLC) patients [85]. Lecomte and coworkers used p16 promoter hypermethylation and K-ras mutations in combination to classify tumorderived DNA in plasma. They reported improved survival for CRC patients showing no tumor-derived DNA in the pre-therapeutic plasma samples [86].

Compared to the analysis of ras, the detection of p53 alterations is especially laborious owing to the potential presence of mutations along several exons. Despite this fact, numerous groups have searched for p53 mutations in serum/plasma DNA, probably due to the p53 alterations known to exist in most malignancies. To our knowledge no valid study has yet been published concerning p53 mutations as a single marker in serum/plasma for prognostication of cancer patients. Most studies have analyzed p53 mutations in serum/plasma together with other alterations, such as microsatellite changes and gene hypermethylation: Silva and coworkers were able to detect tumor-derived DNA (six microsatellite markers and p53 mutations) in $43 \%$ of patients with breast cancer. Moreover, they revealed tumor-derived DNA in plasma to serve as a predictor of disease-free survival in univariate analysis, whereas they found only independent borderline significance in multivariate analysis [87]. Furthermore, it has been reported that small cell lung cancer (SCLC) patients with microsatellite modifications and p53 mutations showed a significant difference in survival as compared with patients bearing only one of these molecular changes [33]. The predictive value was additionally evaluated by looking at tumor-derived DNA in plasma during follow-up. In 15 cases it was possible to find a correlation either between tumor response and disappearance of abnormal plasma DNA, or between tumor progression and persistence of plasma alterations [33]. Silva and coworkers also presented a study which describes a possible predictive value of tumor-derived DNA in plasma of breast cancer patients during followup, showing a relation between persistence of tumorderived DNA in plasma four to six weeks after mastectomy to bad-prognosis histological parameters suggesting undetectable micrometastatic disease [25]. However, from the sensitivity and overall detection rates it is clear that despite the predominance of p53 alterations in human malignancies the analysis of p53 mutations in plasma or serum is technically cumbersome and probably not sufficient per se for prognostic purposes (for summary see Table 1).

\subsection{Microsatellite alterations}

Of all the targets analyzed in serum/plasma DNA, microsatellites alterations have been the source of the most controversies. Although, microsatellite analysis is generally easy to perform, a main concern has been the purity of tumor-derived DNA in plasma and serum, because a significant proportion of serum DNA is thought to derive from in vitro lysis of normal hematological cells, and even in plasma the fraction of tumor-derived DNA is highly variable. It requires tumor DNA within DNA originating from benign sources at a ratio of $0.5 \%$ to $5 \%$ when targeting microsatellite instability (MIN) and more than $10 \%$ to $20 \%$ when targeting loss of heterozygosity ( $\mathrm{LOH})$. In addition, microsatellite analysis using small DNA concentrations, such as those isolated from plasma/serum, is prone to technical artifacts. Longer alleles (> $200 \mathrm{bp}$ ) are more likely to display false-positive LOH than are their shorter counterparts. In CNAPS analysis, the underlying difficulty of amplifying longer microsatellite sequences can be ascribed to the highly fragmented nature of plasma/serum DNA (for review see [14,82]). Despite these limitations, microsatellite alterations including $\mathrm{LOH}$ have been found not only in plasma but also in serum (for review see [13, 14]). Moreover, some studies reported a prognostic value for microsatellite alteration in serum/plasma of cancer patients as a single marker or in combination with hypermethylated DNA or gene mutations:

As above-mentioned, Silva and coworkers were able to detect tumor-derived DNA (six microsatellite mark- 


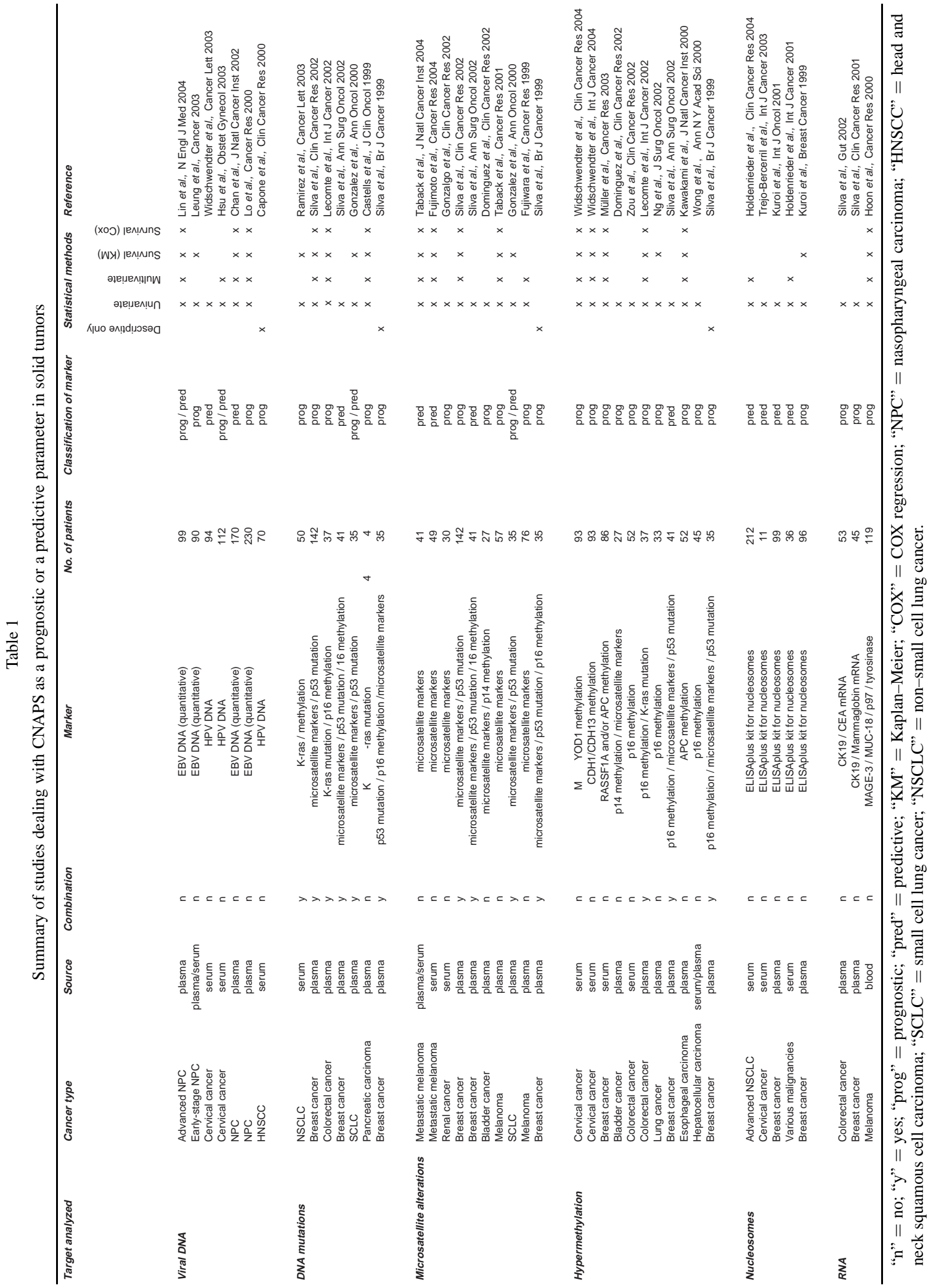


ers and p53 mutations) in patients with breast cancer. Additionally, they demonstrated this tumor-derived DNA in plasma serving as a predictor of disease-free survival in univariate analysis [87]. The same group reported a possible predictive value of tumor-derived DNA (classified as microsatellite alterations, p53 mutations or p16 hypermethylation) in plasma of breast cancer patients during follow-up on the basis of a relation observed between the persistence of tumor-derived DNA in plasma four to six weeks after mastectomy to bad-prognosis histological parameters [25]. Furthermore, Gonzalez and coworkers reported that SCLC patients with microsatellite modifications and p53 mutations showed a significant difference in survival as compared with patients bearing only one of these molecular changes [33]. In melanoma patients, one group found an association between plasma microsatellite alterations and disease stage, progression and survival rates. The analysis was performed with eight to ten markers mapping up to six chromosomal regions showing frequent LOH in tumors $[37,88]$. Very recently, the same group reported a predictive value of microsatellite alterations in plasma of metastatic melanoma patients. The presence of $\mathrm{LOH}$ was statistically significant and independently associated with disease progression in multivariate analysis [36]. It has been reported that circulating tumor-specific DNA in serum of renal cancer patients can be detected by microsatellite analysis ( 28 microsatellite markers [89]). The same group evaluated the postoperative clinical course of patients with renal cancer identified preoperatively by microsatellite analysis (28 microsatellite markers) and found that the frequency of microsatellite alterations $(\mathrm{LOH})$ detected in the preoperative serum of patients with renal cancer served as a prognostic indicator for disease recurrence [90]. With regard to bladder cancer, Dominguez and coworkers reported a link between plasma LOH and disease recurrence [91].

Apoptotic protease-activating factor 1 (APAF-1) is an essential downstream target of p53 in the intrinsic apoptotic pathway. Loss of APAF-1 can aid tumor cells evading immune attack-induced death, circumvent inherent programmed cell death, and resist cancer chemo-, immuno-, and radiotherapy. Recently, it was demonstrated that the presence of allelic imbalance $(\mathrm{AI}=\mathrm{LOH})$ in the APAF-1 gene region in metastatic melanoma tumors is associated with poor disease outcome [92]. Additionally, it was demonstrated that circulating DNA with AI on the APAF-1 gene locus has the potential to predict tumor response to chemotherapy ([93]; for summary see Table 1).

\subsection{DNA methylation}

An increasing number of studies have reported the presence of methylated DNA in serum/plasma and other body fluids of patients with various types of malignancies and the absence of methylated DNA in normal control patients (for review see [42]). Concerning the prognostic or predictive value of circulating methylated DNA in serum or plasma of cancer patients only a few reports have been published: the first was presented by Kawakami and coworkers in the year 2000 and reported high plasma levels of methylated APC in plasma of esophageal carcinoma patients to be statistically significantly associated with reduced survival [94]. One of the targets most frequently analyzed is p16 tumor suppressor gene methylation status in the bloodstream of cancer patients. One study reported a correlation between p16 methylation in CRC patients and later Duke's stage, suggesting a possible prognostic potential. Newertheless, the prognostic potential was not statistically evaluated [95]. Another study looked at only a very small number of patients and stated that the presence of plasma p16 methylation in NSCLC patients is associated with advanced TNM staging, poor survival and shorter disease-free survival [96]. The methylation status of p16 in the bloodstream of breast cancer patients has been assessed as a single marker [97], or in conjunction with additional alterations [24,25]. However, none of these studies identified clinical associations with p16 gene methylation per se. This might be the consequence of the low prevalence of p16 methylation in breast tumor tissue (22-23\%), which resulted in overall detection rates in plasma of only $10 \%$ to $14 \%$. Better results were obtained in hepatocellular carcinoma, where two studies found methylation of p16 in about $70 \%$ of tumors $[98,99]$. In one of these studies the authors suggest that aberrant plasma/serum p16 methylation may be strongly associated with more aggressive phenotypes of hepatic carcinoma and with development of tumor recurrence or metastasis [99]. Additionally, plasma p14ARF promoter hypermethylation was reported to be associated with the presence of multicentric foci, larger tumors and relapse of the disease [91].

For the past five years our research group was mainly interested in evaluating DNA methylation changes in serum of cancer patients. Using a new means of DNA methylation marker evaluation (as described above) we analyzed 39 genes in serum of breast cancer patients. Finally, we established that RASSF1A and/or APC methylation in serum of breast cancer patients is inde- 
pendently associated with poor disease outcome. Furthermore, DNA methylation of these genes in pretherapeutic sera of breast cancer patients is more powerful than standard prognostic parameters [75]. When studying the prognostic potential of methylation markers in sera of cervical cancer patients we detected MYODI methylation status to be significantly associated with better disease-free and overall survival in univariate analysis [79]. Additionally, we found that cervical cancer patients with unmethylated $\mathrm{CDH} 1 / \mathrm{CDH} 13$ methylation showed significantly better disease-free survival in univariate and multivariate analysis [78]. In summary, several prognostic DNA methylation markers in the serum of cancer patients have been detected. There is great potential for the use of these epigenetic markers in clinical, routine risk assessment in patients with various malignancies (for summary see Table 1).

\subsection{Viral nucleic acids}

Viruses such as human papillomavirus (HPV) and Epstein-Barr virus (EBV) are etiological factors in various malignancies. In addition to tumor nucleic acids from endogenous sources, analysis of tumor-associated viral DNA has rapidly emerged as a molecular tool for initial diagnosis and follow-up monitoring in defined populations of cancer patients. In recent years it has been seen that it is possible to use cell-free EBV DNA in plasma of nasopharyngeal carcinoma (NPC) patients to monitor the response to a given treatment or to evaluate the prognosis of these patients (for review see [13,14]). The clinical significance is seen from the fact that those in whom the concentrations do not reach zero (or at least decrease to a low value) subsequently relapse [43, 44]. Chan and coworkers found that patients with EBVassociated NPC had persistently elevated EBV DNA levels in their plasma/serum, whereas patients after recovery from benign mononucleosis (caused by EBV) did not $[44,100]$. It was found that those patients suffering from neoplasia and showing high levels of EBV DNA demonstrated a poorer prognosis. Quantitative determination of EBV DNA also yielded predictive information, because decreasing levels strongly correlated with favorable response to therapy $[45,46,100$, $101]$. Very recently, one group confirmed the prognostic and predictive value of plasma EBV DNA measurement in NPC patients [102]. Therefore, determination of viral DNA levels seems to be close to becoming a routine procedure in these patients. The methodology may also have potential for clinical application in other virus-associated malignancies, such as lymphoma and gastric cancer [49,103].

HPV infection is an etiological factor in cervical carcinoma. Recently, detection of HPV DNA in serum/plasma of patients with cervical cancer and HPV-associated head and neck squamous cell carcinoma was described [50-53]. Hsu and coworkers reported positive HPV DNA in serum of early-stage cervical cancer patients to be significantly associated with poor prognosis factors that warrant adjuvant therapy [104]. Additionally, it has been suggested that circulating HPV DNA in serum of head and neck squamous cell carcinoma (HNSCC) patients has the potential to identify those patients at risk for more aggressive disease despite a low detection rate [51]. Very recently, we were able to demonstrate that serum HPV DNA seems to reflect biological activity of cervical cancer, and furthermore, that serum HPV DNA might be a useful additional marker for early detection of recurrence in cervical cancer patients ([54]; for summary see Table 1).

\subsection{Nucleosomes}

Nucleosomes originate from endonuclease cleavage of chromatin during apoptotic cell death, and are composed of a histone octamer core wrapped with $180 \mathrm{bp}-$ 200 bp DNA. It is now widely accepted that nucleosomes, and in particular mononucleosomes, are the form in which cell-free DNA circulates in the bloodstream (for review see [14]). Kuroi and coworkers reported a significant increase in nucleosome levels in breast cancer patients as compared with healthy controls. Otherwise, no correlation was detected with the most important clinicopathological features or prognosis of breast cancer patients [55]. These data were partly corroborated by the same authors in a subsequent study reporting that pretreatment baseline circulating nucleosome levels decreased markedly when response was achieved, whereas there was no decrease in the case of either stable disease or progressive disease, indicating a possible predictive potential for a given treatment in breast cancer patients [105]. Another study suggested that determination of circulating nucleosomes pre - and post-treatment could be useful in predicting response to chemotherapy in cervical cancer patients [106]. Unfortunately, only a small group of patients was analyzed, for which reason these results have to be further evaluated. Additionally, Holdenrieder and coworkers reported that the timing and extent to which nucleosome levels varied during radiation or 
chemotherapy correlated with clinical outcome [107], but the predictive potential of circulating nucleosomes can not be sufficiently validated because of the small number of patients analyzed during follow-up and the several different malignancies included in this study. Very recently, Holdenrieder and coworkers found circulating nucleosomes in to represent independent predictors of therapy response in patients with stage III and IV NSCLC undergoing chemotherapy ([56]; for summary see Table 1). Despite these promising results, further studies must be undertaken to address the predictive potential of circulating nucleosomes.

\subsection{Mutated mitochondrial DNA}

Each human cell contains several hundred copies of mitochondrial DNA (mtDNA) that encodes respiratory chain subunits, tRNAs, and rRNAs. In recent years, several mutations have been described in patients with colorectal cancer, bladder cancer, lung cancer, and head and neck cancer [14,57]. Recently, mtDNA mutations have been reported in the plasma of patients with early prostate cancer [58], in the serum/plasma of patients with hepatocellular carcinoma [59,60], and in the serum of CRC patients [61]. Taken together, all published data indicate that mtDNA might be highly diluted in the plasma of cancer patients, probably making the detection of previously unknown mutations difficult (for review see $[13,14]$ ). However, detailed studies of the correlation between tumor-derived mtDNA mutations in plasma/serum and clinical parameters including patient outcome during follow-up remain to be performed (for summary see Table 1).

\subsection{Circulating $m R N A$}

Cell-free mRNA can also be detected in serum or plasma. This gives rise to the suggestion that expression profiling can be performed in patient bloodstream. In patients with cancer, RNA may derive from tumorassociated viruses (e.g. DNA viruses that have an RNA genome as an obligatory part of their replicative strategy) or directly from the tumor (for review see $[13,14$, 82]). Recently, it was reported that tumor-derived tyrosinase mRNA was detected in four of six patients with metastatic melanoma but not in healthy controls [62]. A similar detection rate for tyrosinase mRNA was demonstrated by a second work [63]. Additionally, telomerase mRNA has be detected in serum/plasma of patients with various types of neoplasia, including breast cancer [64] or CRC $[65,66]$. In lung cancer, disease was detected in $100 \%$ of patients using Her2/neu and hnRNP-B1 serum mRNA as markers [108]. Another work analyzed 5T4 mRNA in the serum of breast and lung cancer patients [109]. Since expression of 5T4 in epithelial tumors is associated with metastatic potential and worse prognosis, the detection of this marker in serum might be particularly valuable. When researching a putative prognostic potential of circulating mRNA, Silva and coworkers reported circulating cytokeratin 19 (CK19) and carcinoembryonic antigen (CEA) mRNA in plasma of CRC patients and CK19 and mammoglobin mRNA in plasma of breast cancer patients to be associated with advanced stages and circulating tumor cells or poor prognostic parameters [110,111]. Therefore, it was suggested that these markers can be used for prognostication or to evaluate disease spread during progression. Hoon and coworkers used four different mRNA markers (MAGE-3, MUC-18, p97 and tyrosinase) in combination to address their prognostic potential in the blood of melanoma patients. They found that the number of RT-PCR markers positive in blood (one and two vs. three and four) was an independent prediction factor of disease recurrence ([112]; for summary see Table 1).

\section{Conclusions}

It is now widely accepted that there is a need for development of molecular markers of cancer that can be used for clinical prognostication and monitoring. The majority of reports evaluating a prognostic test in solid tumors face one major obstacle: the need for invasive procedures to obtain adequate testing material. Approximately a decade ago tumor-derived circulating nucleic acids in the plasma or serum of cancer patients were introduced as a noninvasive tool for cancer detection. The easy accessibility of CNAPS now opens up a new field for prognostic testing and therapy monitoring during follow-up.

Despite extensive testing of various molecular markers, including CNAPS, for their putative prognostic value, only very few have actually gained widespread clinical use. A possible reason for this lack of progress and the controversy in this field stems from poorly designed and analyzed studies. We want to emphasize the difference between a prognostic and a predictive factor in patient bloodstream, because the distinction between prognostic and predictive factors can critically affect the results of a clinical or laboratory investigation and ultimately delay the introduction of promising molecu- 
lar markers such as CNAPS as routine clinical prognostic and predictive markers. If outcome studies include patients with different types of treatment, their eventual confounding effect must be assessed using stratification or multivariate models.

Beside the often unappreciated issue of prognosis and prediction, many other aspects further complicate the interpretation of studies with regard to prognosis. Most studies are retrospective, include only small numbers of patients and do not control for other confounding prognostic variables. Additionally, differing lengths of follow-up and different endpoints (response, disease-free survival, overall survival, relative risk of relapse or death) contribute to misinterpretation of prognostic studies. On the one hand, we want emphasize the importance of a well-designed (prospective) study, but on the other hand we are aware that it is very important to initially use retrospective analysis of serum or plasma samples to determine promising markers for further analysis. This review discusses a new promising means of marker evaluation using a retrospective study design and only blood samples. At bottom, every putative prognostic parameter has to be tested in a prospective, multicenter study before it can be introduced in clinical routine.

In summary, a possible means of serum/plasma marker evaluation in a well-designed retrospective study including as many patients as possible, ideally without any form of adjuvant treatment or, if not possible, with patients receiving the same form of adjuvant treatment. Evaluated promising candidates for prognostication or therapy monitoring are then further checked in well-designed prospective multicenter studies. If these criteria are met, it would be possible to introduce CNAPS markers into clinical routine for prognostication and monitoring during follow-up within the next five to seven years.

\section{Acknowledgements}

This work was supported by a grant from "Jubiläumsfonds der Österreichischen Nationalbank"; Project \#10929 and by a grant from "Österreichische Krebshilfe - Krebsgesellschaft Tirol”.

\section{References}

[1] P. Mandel and P. Métais, Les acides nucléiques du plasma sanguin chez l'Homme, CR Acad Sci Paris 142 (1948), 241243.
[2] E.M. Tan, P.H. Schur, R.I. Carr and H.G. Kunkel, Deoxyribonucleic acid (DNA) and antibodies to DNA in the serum of patients with systemic lupus erythematosus, J Clin Invest $\mathbf{4 5}$ (1966), 1732-1740.

[3] S.A. Leon, B. Shapiro, D.M. Sklaroff and M.J. Yaros, Free DNA in the serum of cancer patients and the effect of therapy, Cancer Res 37 (1977), 646-650.

[4] B. Shapiro, M. Chakrabarty, E.M. Cohn and S.A. Leon, Determination of circulating DNA levels in patients with benign or malignant gastrointestinal disease, Cancer 51 (1983), 21162120.

[5] M. Stroun, P. Anker, P. Maurice, J. Lyautey, C. Lederrey and M. Beljanski, Neoplastic characteristics of the DNA found in the plasma of cancer patients, Oncology 46 (1989), 318-322.

[6] G.D. Sorenson, D.M. Pribish, F.H. Valone, V.A. Memoli, D.J. Bzik and S.L. Yao, Soluble normal and mutated DNA sequences from single-copy genes in human blood, Cancer Epidemiol Biomarkers Prev 3 (1994), 67-71.

[7] V. Vasioukhin, P. Anker, P. Maurice, J. Lyautey, C. Lederrey and M. Stroun, Point mutations of the N-ras gene in the blood plasma DNA of patients with myelodysplastic syndrome or acute myelogenous leukaemia, Br J Haematol 86 (1994), 774 779.

[8] S. Jahr, H. Hentze, S. Englisch, D. Hardt, F.O. Fackelmayer, R.D. Hesch and R. Knippers, DNA fragments in the blood plasma of cancer patients: quantitations and evidence for their origin from apoptotic and necrotic cells, Cancer Res 61 (2001), 1659-1665.

[9] G. Sozzi, D. Conte, L. Mariani, V.S. Lo, L. Roz, C. Lombardo, M.A. Pierotti and L. Tavecchio, Analysis of circulating tumor DNA in plasma at diagnosis and during follow-up of lung cancer patients, Cancer Res 61 (2001), 4675-4678.

[10] X. Chen, H. Bonnefoi, S. Diebold-Berger, J. Lyautey, C. Lederrey, E. Faltin-Traub, M. Stroun and P. Anker, Detecting tumor-related alterations in plasma or serum DNA of patients diagnosed with breast cancer, Clin Cancer Res 5 (1999), 22972303.

[11] Y.Y. Lui, K.W. Chik, R.W. Chiu, C.Y. Ho, C.W. Lam and Y.M. Lo, Predominant hematopoietic origin of cell-free DNA in plasma and serum after sex-mismatched bone marrow transplantation, Clin Chem 48 (2002), 421-427.

[12] T.H. Lee, L. Montalvo, V. Chrebtow and M.P. Busch, Quantitation of genomic DNA in plasma and serum samples: higher concentrations of genomic DNA found in serum than in plasma, Transfusion 41 (2001), 276-282.

[13] P.J. Johnson and Y.M. Lo, Plasma nucleic acids in the diagnosis and management of malignant disease, Clin Chem 48 (2002), 1186-1193.

[14] A. Ziegler, U. Zangemeister-Wittke and R.A. Stahel, Circulating DNA: a new diagnostic gold mine?, Cancer Treat Rev 28 (2002), 255-271.

[15] T. Minamoto, N. Yamashita, A. Ochiai, M. Mai, T. Sugimura, Z. Ronai and H. Esumi, Mutant K-ras in apparently normal mucosa of colorectal cancer patients. Its potential as a biomarker of colorectal tumorigenesis, Cancer 75 (1995), 1520-1526.

[16] G.D. Sorenson, Detection of mutated KRAS2 sequences as tumor markers in plasma/serum of patients with gastrointestinal cancer, Clin Cancer Res 6 (2000), 2129-2137.

[17] G.D. Sorenson, A review of studies on the detection of mutated KRAS2 sequences as tumor markers in plasma/serum of patients with gastrointestinal cancer, Ann N Y Acad Sci 906 (2000), 13-16. 
[18] G.D. Kirk, A.M. Camus-Randon, M. Mendy, J.J. Goedert, P. Merle, C. Trepo, C. Brechot, P. Hainaut and R. Montesano, Ser-249 p53 mutations in plasma DNA of patients with hepatocellular carcinoma from The Gambia, J Natl Cancer Inst 92 (2000), 148-153.

[19] P.E. Jackson, G.S. Qian, M.D. Friesen, Y.R. Zhu, P. Lu, J.B. Wang, Y. Wu, T.W. Kensler, B. Vogelstein and J.D. Groopman, Specific p53 mutations detected in plasma and tumors of hepatocellular carcinoma patients by electrospray ionization mass spectrometry, Cancer Res 61 (2001), 33-35.

[20] Z.M. Shao, J. Wu, Z.Z. Shen and M. Nguyen, p53 mutation in plasma DNA and its prognostic value in breast cancer patients, Clin Cancer Res 7 (2001), 2222-2227.

[21] J.M. Silva, R. Gonzalez, G. Dominguez, J.M. Garcia, P. Espana and F. Bonilla, TP53 gene mutations in plasma DNA of cancer patients, Genes Chromosomes Cancer 24 (1999), $160-161$.

[22] F. Mayall, G. Jacobson, R. Wilkins and B. Chang, Mutations of p53 gene can be detected in the plasma of patients with large bowel carcinoma, J Clin Pathol 51 (1998), 611-613.

[23] C.D. Gocke, F.A. Benko, M.S. Kopreski and T.J. McGarrity, p53 and APC mutations are detectable in the plasma and serum of patients with colorectal cancer (CRC) or adenomas, Ann N Y Acad Sci 906 (2000), 44-50.

[24] J.M. Silva, G. Dominguez, J.M. Garcia, R. Gonzalez, M.J. Villanueva, F. Navarro, M. Provencio, S. San Martin, P. Espana and F. Bonilla, Presence of tumor DNA in plasma of breast cancer patients: clinicopathological correlations, Cancer Res 59 (1999), 3251-3256.

[25] J.M. Silva, J.M. Garcia, G. Dominguez, J. Silva, C. Miralles, B. Cantos, S. Coca, M. Provencio, P. Espana and F. Bonilla, Persistence of tumor DNA in plasma of breast cancer patients after mastectomy, Ann Surg Oncol 9 (2002), 71-76.

[26] K. Hibi, C.R. Robinson, S. Booker, L. Wu, S.R. Hamilton, D. Sidransky and J. Jen, Molecular detection of genetic alterations in the serum of colorectal cancer patients, Cancer Res $\mathbf{5 8}$ (1998), 1405-1407.

[27] R. Dahse, M. Utting, W. Werner, B. Schimmel, U. Claussen and K. Junker, TP53 alterations as a potential diagnostic marker in superficial bladder carcinoma and in patients serum, plasma and urine samples, Int J Oncol 20 (2002), 107-115.

[28] F. Coulet, H. Blons, A. Cabelguenne, T. Lecomte, O. Lacourreye, D. Brasnu, P. Beaune, J. Zucman and P. Laurent-Puig, Detection of plasma tumor DNA in head and neck squamous cell carcinoma by microsatellite typing and p53 mutation analysis, Cancer Res 60 (2000), 707-711.

[29] E. Ling, A. Fich, S. Man, M. Wolfson, R. Mikhailowsky and S.A. Lamprecht, Detection of tumor mutant APC DNA in plasma of patients with sporadic colorectal cancer, In Vivo $\mathbf{1 4}$ (2000), 543-546.

[30] P.W. Chiang, D.G. Beer, W.L. Wei, M.B. Orringer and D.M. Kurnit, Detection of erbB-2 amplifications in tumors and sera from esophageal carcinoma patients, Clin Cancer Res $\mathbf{5}$ (1999), 1381-1386.

[31] N. Bruhn, T. Beinert, C. Oehm, B. Jandrig, I. Petersen, X.Q. Chen, K. Possinger and M. Fleischhacker, Detection of microsatellite alterations in the DNA isolated from tumor cells and from plasma DNA of patients with lung cancer, Ann $N Y$ Acad Sci 906 (2000), 72-82.

[32] X.Q. Chen, M. Stroun, J.L. Magnenat, L.P. Nicod, A.M. Kurt, J. Lyautey, C. Lederrey and P. Anker, Microsatellite alterations in plasma DNA of small cell lung cancer patients, Nat Med $\mathbf{2}$ (1996), 1033-1035.
[33] R. Gonzalez, J.M. Silva, A. Sanchez, G. Dominguez, J.M. Garcia, X.Q. Chen, M. Stroun, M. Provencio, P. Espana, P. Anker and F. Bonilla, Microsatellite alterations and TP53 mutations in plasma DNA of small-cell lung cancer patients: followup study and prognostic significance, Ann Oncol 11 (2000), 1097-1104.

[34] H. Nawroz, W. Koch, P. Anker, M. Stroun and D. Sidransky, Microsatellite alterations in serum DNA of head and neck cancer patients, Nat Med 2 (1996), 1035-1037.

[35] B. Taback, A.E. Giuliano, N.M. Hansen and D.S. Hoon, Microsatellite alterations detected in the serum of early stage breast cancer patients, Ann N Y Acad Sci 945 (2001), 22-30.

[36] B. Taback, S.J. O'Day, P.D. Boasberg, S. Shu, P. Fournier, R. Elashoff, H.J. Wang and D.S. Hoon, Circulating DNA microsatellites: molecular determinants of response to biochemotherapy in patients with metastatic melanoma, $\mathrm{J} \mathrm{Natl}$ Cancer Inst 96 (2004), 152-156.

[37] B. Taback, Y. Fujiwara, H.J. Wang, L.J. Foshag, D.L. Morton and D.S. Hoon, Prognostic significance of circulating microsatellite markers in the plasma of melanoma patients, Cancer Res 61 (2001), 5723-5726.

[38] C. Goessl, R. Heicappell, R. Munker, P. Anker, M. Stroun, H. Krause, M. Muller and K. Miller, Microsatellite analysis of plasma DNA from patients with clear cell renal carcinoma, Cancer Res 58 (1998), 4728-4732.

[39] P.A. Jones and S.B. Baylin, The fundamental role of epigenetic events in cancer, Nat Rev Genet 3 (2002), 415-428.

[40] P.W. Laird, Early detection: The power and the promise of DNA methylation markers, Nat Rev Cancer 3 (2003), 253266.

[41] J.G. Herman and S.B. Baylin, Gene silencing in cancer in association with promoter hypermethylation, N. Engl. J. Med. 349 (2003), 2042-2054.

[42] H.M. Muller and M. Widschwendter, Methylated DNA as a possible screening marker for neoplastic disease in several body fluids, Expert Rev Mol Diagn 3 (2003), 443-458.

[43] Y.M. Lo, L.Y. Chan, A.T. Chan, S.F. Leung, K.W. Lo, J. Zhang, J.C. Lee, N.M. Hjelm, P.J. Johnson and D.P. Huang, Quantitative and temporal correlation between circulating cell-free Epstein-Barr virus DNA and tumor recurrence in nasopharyngeal carcinoma, Cancer Res 59 (1999), 5452-5455.

[44] Y.M. Lo, L.Y. Chan, K.W. Lo, S.F. Leung, J. Zhang, A.T. Chan, J.C. Lee, N.M. Hjelm, P.J. Johnson and D.P. Huang, Quantitative analysis of cell-free Epstein-Barr virus DNA in plasma of patients with nasopharyngeal carcinoma, Cancer Res 59 (1999), 1188-1191.

[45] Y.M. Lo, A.T. Chan, L.Y. Chan, S.F. Leung, C.W. Lam, D.P. Huang and P.J. Johnson, Molecular prognostication of nasopharyngeal carcinoma by quantitative analysis of circulating Epstein-Barr virus DNA, Cancer Res 60 (2000), 6878-6881.

[46] A. Gallagher, A.A. Armstrong, J. MacKenzie, L. Shield, G. Khan, A. Lake, S. Proctor, P. Taylor, G.B. Clements and R.F. Jarrett, Detection of Epstein-Barr virus (EBV) genomes in the serum of patients with EBV-associated Hodgkin's disease, Int J Cancer 84 (1999), 442-448.

[47] H.J. Wagner, F. Schlager, A. Claviez and P. Bucsky, Detection of Epstein-Barr virus DNA in peripheral blood of paediatric patients with Hodgkin's disease by real-time polymerase chain reaction, Eur J Cancer 37 (2001), 1853-1857.

[48] K.I. Lei, L.Y. Chan, W.Y. Chan, P.J. Johnson and Y.M. Lo, Quantitative analysis of circulating cell-free Epstein-Barr virus (EBV) DNA levels in patients with EBV-associated lymphoid malignancies, Br J Haematol 111 (2000), 239-246. 
[49] K.I. Lei, L.Y. Chan, W.Y. Chan, P.J. Johnson and Y.M. Lo, Diagnostic and prognostic implications of circulating cell-free Epstein-Barr virus DNA in natural killer/T-cell lymphoma, Clin Cancer Res 8 (2002), 29-34.

[50] S.M. Dong, S.I. Pai, S.H. Rha, A. Hildesheim, R.J. Kurman, P.E. Schwartz, R. Mortel, L. McGowan, M.D. Greenberg, W.A. Barnes and D. Sidransky, Detection and quantitation of human papillomavirus DNA in the plasma of patients with cervical carcinoma, Cancer Epidemiol Biomarkers Prev 11 (2002), 3-6.

[51] R.B. Capone, S.I. Pai, W.M. Koch, M.L. Gillison, H.N. Danish, W.H. Westra, R. Daniel, K.V. Shah and D. Sidransky, Detection and quantitation of human papillomavirus (HPV) DNA in the sera of patients with HPV-associated head and neck squamous cell carcinoma, Clin Cancer Res 6 (2000), 4171-4175.

[52] W. Pornthanakasem, K. Shotelersuk, W. Termrungruanglert, N. Voravud, S. Niruthisard and A. Mutirangura, Human papillomavirus DNA in plasma of patients with cervical cancer, BMC Cancer 1 (2001), 2.

[53] V.W. Liu, P. Tsang, A. Yip, T.Y. Ng, L.C. Wong and H.Y. Ngan, Low incidence of HPV DNA in sera of pretreatment cervical cancer patients, Gynecol Oncol 82 (2001), 269-272.

[54] A. Widschwendter, A. Blassnig, A. Wiedemair, E. MullerHolzner, H.M. Muller and C. Marth, Human papillomavirus DNA in sera of cervical cancer patients as tumor marker, Cancer Lett 202 (2003), 231-239.

[55] K. Kuroi, C. Tanaka and M. Toi, Plasma Nucleosome Levels in Node-Negative Breast Cancer Patients, Breast Cancer 6 (1999), 361-364.

[56] S. Holdenrieder, P. Stieber, J. Von Pawel, H. Raith, D. Nagel, K. Feldmann and D. Seidel, Circulating nucleosomes predict the response to chemotherapy in patients with advanced nonsmall cell lung cancer, Clin Cancer Res 10 (2004), 5981-5987.

[57] K. Polyak, Y. Li, H. Zhu, C. Lengauer, J.K. Willson, S.D. Markowitz, M.A. Trush, K.W. Kinzler and B. Vogelstein, Somatic mutations of the mitochondrial genome in human colorectal tumours, Nat Genet 20 (1998), 291-293.

[58] C. Jeronimo, S. Nomoto, O.L. Caballero, H. Usadel, R. Henrique, G. Varzim, J. Oliveira, C. Lopes, M.S. Fliss and D. Sidransky, Mitochondrial mutations in early stage prostate cancer and body fluids, Oncogene 20 (2001), 5195-5198.

[59] S. Nomoto, K. Yamashita, K. Koshikawa, A. Nakao and D. Sidransky, Mitochondrial D-loop mutations as clonal markers in multicentric hepatocellular carcinoma and plasma, Clin Cancer Res 8 (2002), 481-487.

[60] O. Okochi, K. Hibi, T. Uemura, S. Inoue, S. Takeda, T. Kaneko and A. Nakao, Detection of mitochondrial DNA alterations in the serum of hepatocellular carcinoma patients, Clin Cancer Res 8 (2002), 2875-2878.

[61] K. Hibi, H. Nakayama, T. Yamazaki, T. Takase, M. Taguchi, Y. Kasai, K. Ito, S. Akiyama and A. Nakao, Detection of mitochondrial DNA alterations in primary tumors and corresponding serum of colorectal cancer patients, Int J Cancer 94 (2001), 429-431.

[62] M.S. Kopreski, F.A. Benko, L.W. Kwak and C.D. Gocke, Detection of tumor messenger RNA in the serum of patients with malignant melanoma, Clin Cancer Res 5 (1999), 19611965.

[63] D.O. Hasselmann, G. Rappl, M. Rossler, S. Ugurel, W. Tilgen and U. Reinhold, Detection of tumor-associated circulating mRNA in serum, plasma and blood cells from patients with disseminated malignant melanoma, Oncol Rep 8 (2001), 115118.
[64] X.Q. Chen, H. Bonnefoi, M.F. Pelte, J. Lyautey, C. Lederrey, S. Movarekhi, P. Schaeffer, H.E. Mulcahy, P. Meyer, M. Stroun and P. Anker, Telomerase RNA as a detection marker in the serum of breast cancer patients, Clin Cancer Res 6 (2000), 3823-3826.

[65] S.M. Lledo, E. Garcia-Granero, F. Dasi, R. Ripoli, S.A. Garcia, A. Cervantes and S.F. Alino, Real time quantification in plasma of human telomerase reverse transcriptase (hTERT) mRNA in patients with colorectal cancer, Colorectal Dis 6 (2004), 236-242.

[66] F. Dasi, S. Lledo, E. Garcia-Granero, R. Ripoll, M. Marugan, M. Tormo, J. Garcia-Conde and S.F. Alino, Real-time quantification in plasma of human telomerase reverse transcriptase (hTERT) mRNA: a simple blood test to monitor disease in cancer patients, Lab Invest 81 (2001), 767-769.

[67] P. Anker, H. Mulcahy, X.Q. Chen and M. Stroun, Detection of circulating tumour DNA in the blood (plasma/serum) of cancer patients, Cancer Metastasis Rev 18 (1999), 65-73.

[68] J.P. Issa, N. Ahuja, M. Toyota, M.P. Bronner and T.A. Brentnall, Accelerated age-related cpg island methylation in ulcerative colitis, Cancer Res 61 (2001), 3573-3577.

[69] H. Nakagawa, G.J. Nuovo, E.E. Zervos, E.W. Martin, Jr., R. Salovaara, L.A. Aaltonen and C.A. de la, Age-related hypermethylation of the 5' region of MLH1 in normal colonic mucosa is associated with microsatellite-unstable colorectal cancer development, Cancer Res 61 (2001), 6991-6995.

[70] T. Habuchi, T. Takahashi, H. Kakinuma, L. Wang, N. Tsuchiya, S. Satoh, T. Akao, K. Sato, O. Ogawa, M.A. Knowles and T. Kato, Hypermethylation at 9q32-33 tumour suppressor region is age-related in normal urothelium and an early and frequent alteration in bladder cancer, Oncogene $\mathbf{2 0}$ (2001), 531-537.

[71] D. Garcia-Olmo, D.C. Garcia-Olmo, J. Ontanon, E. Martinez and M. Vallejo, Tumor DNA circulating in the plasma might play a role in metastasis. The hypothesis of the genometastasis, Histol Histopathol 14 (1999), 1159-1164.

[72] X. Yao, J.F. Hu, M. Daniels, H. Shiran, X. Zhou, H. Yan, H. Lu, Z. Zeng, Q. Wang, T. Li and A.R. Hoffman, A methylated oligonucleotide inhibits IGF2 expression and enhances survival in a model of hepatocellular carcinoma, J Clin Invest 111 (2003), 265-273.

[73] D. Garcia-Olmo and D.C. Garcia-Olmo, Functionality of circulating DNA: the hypothesis of genometastasis, Ann NY Acad Sci 945 (2001), 265-275.

[74] A. Bergsmedh, A. Szeles, M. Henriksson, A. Bratt, M.J. Folkman, A.L. Spetz and L. Holmgren, Horizontal transfer of oncogenes by uptake of apoptotic bodies, Proc Natl Acad Sci USA 98 (2001), 6407-6411.

[75] H.M. Muller, A. Widschwendter, H. Fiegl, L. Ivarsson, G. Goebel, E. Perkmann, C. Marth and M. Widschwendter, DNA methylation in serum of breast cancer patients: an independent prognostic marker, Cancer Res 63 (2003), 7641-7645.

[76] C.A. Klein, T.J. Blankenstein, O. Schmidt-Kittler, M. Petronio, B. Polzer, N.H. Stoecklein and G. Riethmuller, Genetic heterogeneity of single disseminated tumour cells in minimal residual cancer, Lancet 360 (2002), 683-689.

[77] H.M. Muller, H. Fiegl, A. Widschwendter and M. Widschwendter, Prognostic DNA Methylation Marker in Serum of Cancer Patients, Ann N Y Acad Sci 1022 (2004), 44-49.

[78] A. Widschwendter, L. Ivarsson, A. Blassnig, H.M. Muller, H. Fieg1, A. Wiedemair, E. Muller-Holzner, G. Goebel, C. Marth and $\mathrm{M}$. Widschwendter, $\mathrm{CDH} 1$ and $\mathrm{CDH} 13$ methylation in serum is an independent prognostic marker in cervical cancer patients, Int J Cancer 109 (2004), 163-166. 
[79] A. Widschwendter, H.M. Muller, H. Fiegl, L. Ivarsson, A. Wiedemair, E. Muller-Holzner, G. Goebel, C. Marth and M. Widschwendter, DNA methylation in serum and tumors of cervical cancer patients, Clin Cancer Res 10 (2004), 565-571.

[80] D.F. Hayes, C. Isaacs and V. Stearns, Prognostic factors in breast cancer: current and new predictors of metastasis, $J$ Mammary Gland Biol Neoplasia 6 (2001), 375-392.

[81] D.F. Hayes, B. Trock and A.L. Harris, Assessing the clinical impact of prognostic factors: when is "statistically significant" clinically useful?, Breast Cancer Res Treat 52 (1998), 305319.

[82] C. Goessl, Diagnostic potential of circulating nucleic acids for oncology, Expert Rev Mol Diagn 3 (2003), 431-442.

[83] T. Yamada, S. Nakamori, H. Ohzato, S. Oshima, T. Aoki, N. Higaki, K. Sugimoto, K. Akagi, Y. Fujiwara, I. Nishisho, M. Sakon, M. Gotoh and M. Monden, Detection of K-ras gene mutations in plasma DNA of patients with pancreatic adenocarcinoma: correlation with clinicopathological features, Clin Cancer Res 4 (1998), 1527-1532.

[84] A. Castells, P. Puig, J. Mora, J. Boadas, L. Boix, E. Urgell, M. Sole, G. Capella, F. Lluis, L. Fernandez-Cruz, S. Navarro and A. Farre, K-ras mutations in DNA extracted from the plasma of patients with pancreatic carcinoma: diagnostic utility and prognostic significance, J Clin Oncol 17 (1999), 578-584.

[85] J.L. Ramirez, C. Sarries, P.L. de Castro, B. Roig, C. Queralt, D. Escuin, A. de, I, J.M. Sanchez, J.L. Manzano, M. Margeli, J.J. Sanchez, J. Astudillo, M. Taron and R. Rosell, Methylation patterns and K-ras mutations in tumor and paired serum of resected non-small-cell lung cancer patients, Cancer Lett 193 (2003), 207-216

[86] T. Lecomte, A. Berger, F. Zinzindohoue, S. Micard, B. Landi, H. Blons, P. Beaune, P.H. Cugnenc and P. Laurent-Puig, Detection of free-circulating tumor-associated DNA in plasma of colorectal cancer patients and its association with prognosis, Int J Cancer 100 (2002), 542-548.

[87] J.M. Silva, J. Silva, A. Sanchez, J.M. Garcia, G. Dominguez, M. Provencio, L. Sanfrutos, E. Jareno, A. Colas, P. Espana and F. Bonilla, Tumor DNA in plasma at diagnosis of breast cancer patients is a valuable predictor of disease-free survival, Clin Cancer Res 8 (2002), 3761-3766.

[88] Y. Fujiwara, D.D. Chi, H. Wang, P. Keleman, D.L. Morton, R. Turner and D.S. Hoon, Plasma DNA microsatellites as tumor-specific markers and indicators of tumor progression in melanoma patients, Cancer Res 59 (1999), 1567-1571.

[89] C.F. Eisenberger, M. Schoenberg, C. Enger, S. Hortopan, S. Shah, N.H. Chow, F.F. Marshall and D. Sidransky, Diagnosis of renal cancer by molecular urinalysis, J Natl Cancer Inst 91 (1999), 2028-2032.

[90] M.L. Gonzalgo, C.F. Eisenberger, S.M. Lee, B.J. Trock, F.F. Marshall, S. Hortopan, D. Sidransky and M.P. Schoenberg, Prognostic significance of preoperative molecular serum analysis in renal cancer, Clin Cancer Res 8 (2002), 1878-1881.

[91] G. Dominguez, J. Carballido, J. Silva, J.M. Silva, J.M. Garcia, J. Menendez, M. Provencio, P. Espana and F. Bonilla, p14ARF promoter hypermethylation in plasma DNA as an indicator of disease recurrence in bladder cancer patients, Clin Cancer Res 8 (2002), 980-985.

[92] A. Fujimoto, H. Takeuchi, B. Taback, E.C.Hsueh, D. Elashoff, D.L. Morton and D.S. Hoon, Allelic imbalance of 12q2223 associated with APAF-1 locus correlates with poor disease outcome in cutaneous melanoma, Cancer Res 64 (2004), 2245-2250.

[93] A. Fujimoto, S.J. O’Day, B. Taback, D. Elashoff and D.S. Hoon, Allelic imbalance on $12 \mathrm{q} 22-23$ in serum circulating
DNA of melanoma patients predicts disease outcome, Cancer Res 64 (2004), 4085-4088.

[94] K. Kawakami, J. Brabender, R.V. Lord, S. Groshen, B.D. Greenwald, M.J. Krasna, J. Yin, A.S. Fleisher, J.M. Abraham, D.G. Beer, D. Sidransky, H.T. Huss, T.R. DeMeester, C. Eads, P.W. Laird, D.H. Ilson, D.P. Kelsen, D. Harpole, M.B. Moore, K.D. Danenberg, P.V. Danenberg and S.J. Meltzer, Hypermethylated APC DNA in plasma and prognosis of patients with esophageal adenocarcinoma, J Natl Cancer Inst 92 (2000), 1805-1811.

[95] H.Z. Zou, B.M. Yu, Z.W. Wang, J.Y. Sun, H. Cang, F. Gao, D.H. Li, R. Zhao, G.G. Feng and J. Yi, Detection of aberrant p16 methylation in the serum of colorectal cancer patients, Clin Cancer Res 8 (2002), 188-191.

[96] C.S. Ng, J. Zhang, S. Wan, T.W. Lee, A.A. Arifi, T. Mok, D.Y. Lo and A.P. Yim, Tumor p16M is a possible marker of advanced stage in non-small cell lung cancer, J Surg Oncol 79 (2002), 101-106.

[97] J.M. Silva, G. Dominguez, M.J. Villanueva, R. Gonzalez, J.M. Garcia, C. Corbacho, M. Provencio, P. Espana and F. Bonilla, Aberrant DNA methylation of the p16INK4a gene in plasma DNA of breast cancer patients, Br J Cancer 80 (1999), 1262 1264.

[98] I.H. Wong, Y.M. Lo, J. Zhang, C.T. Liew, M.H. Ng, N. Wong, P.B. Lai, W.Y. Lau, N.M. Hjelm and P.J. Johnson, Detection of aberrant p16 methylation in the plasma and serum of liver cancer patients, Cancer Res 59 (1999), 71-73.

[99] I.H. Wong, P.J. Johnson, P.B. Lai, W.Y. Lau and Y.M. Lo, Tumor-derived epigenetic changes in the plasma and serum of liver cancer patients. Implications for cancer detection and monitoring, Ann N Y Acad Sci 906 (2000), 102-105.

[100] A.T. Chan, Y.M. Lo, B. Zee, L.Y. Chan, B.B. Ma, S.F. Leung, F. Mo, M. Lai, S. Ho, D.P. Huang and P.J. Johnson, Plasma Epstein-Barr virus DNA and residual disease after radiotherapy for undifferentiated nasopharyngeal carcinoma, $J$ Natl Cancer Inst 94 (2002), 1614-1619.

[101] S.F. Leung, A.T. Chan, B. Zee, B. Ma, L.Y. Chan, P.J. Johnson and Y.M. Lo, Pretherapy quantitative measurement of circulating Epstein-Barr virus DNA is predictive of posttherapy distant failure in patients with early-stage nasopharyngeal carcinoma of undifferentiated type, Cancer 98 (2003), 288-291.

[102] J.C. Lin, W.Y. Wang, K.Y. Chen, Y.H. Wei, W.M. Liang, J.S. Jan and R.S. Jiang, Quantification of plasma EpsteinBarr virus DNA in patients with advanced nasopharyngeal carcinoma, N Engl J Med 350 (2004), 2461-2470.

[103] Y.M. Lo, W.Y. Chan, E.K. Ng, L.Y. Chan, P.B. Lai, J.S. Tam and S.C. Chung, Circulating Epstein-Barr virus DNA in the serum of patients with gastric carcinoma, Clin Cancer Res 7 (2001), 1856-1859.

[104] K.F. Hsu, S.C. Huang, J.R. Hsiao, Y.M. Cheng, S.P. Wang and C.Y. Chou, Clinical significance of serum human papillomavirus DNA in cervical carcinoma, Obstet Gynecol 102 (2003), 1344-1351.

[105] K. Kuroi, C. Tanaka and M. Toi, Clinical significance of plasma nucleosome levels in cancer patients, Int J Oncol 19 (2001), 143-148.

[106] C. Trejo-Becerril, E. Perez-Cardenas, H. Trevino-Cuevas, L. Taja-Chayeb, P. Garcia-Lopez, B. Segura-Pacheco, A. Chavez-Blanco, M. Lizano-Soberon, A. Gonzalez-Fierro, I. Mariscal, T. Wegman-Ostrosky and A. Duenas-Gonzalez, Circulating nucleosomes and response to chemotherapy: an in vitro, in vivo and clinical study on cervical cancer patients, Int J Cancer 104 (2003), 663-668. 
[107] S. Holdenrieder, P. Stieber, H. Bodenmuller, M. Busch, G. Fertig, H. Furst, A. Schalhorn, N. Schmeller, M. Untch and D. Seidel, Nucleosomes in serum of patients with benign and malignant diseases, Int J Cancer 95 (2001), 114-120.

[108] M. Fleischhacker, T. Beinert, M. Ermitsch, D. Seferi, K. Possinger, C. Engelmann and B. Jandrig, Detection of amplifiable messenger RNA in the serum of patients with lung cancer, Ann N Y Acad Sci 945 (2001), 179-188.

[109] M.S. Kopreski, F.A. Benko and C.D. Gocke, Circulating RNA as a tumor marker: detection of 5T4 mRNA in breast and lung cancer patient serum, Ann N Y Acad Sci 945 (2001), $172-178$.

[110] J.M. Silva, R. Rodriguez, J.M. Garcia, C. Munoz, J. Silva,
G. Dominguez, M. Provencio, P. Espana and F. Bonilla, Detection of epithelial tumour RNA in the plasma of colon cancer patients is associated with advanced stages and circulating tumour cells, Gut $\mathbf{5 0}$ (2002), 530-534.

[111] J.M. Silva, G. Dominguez, J. Silva, J.M. Garcia, A. Sanchez, O. Rodriguez, M. Provencio, P. Espana and F. Bonilla, Detection of epithelial messenger RNA in the plasma of breast cancer patients is associated with poor prognosis tumor characteristics, Clin Cancer Res 7 (2001), 2821-2825.

[112] D.S. Hoon, P. Bostick, C. Kuo, T. Okamoto, H.J. Wang, R. Elashoff and D.L. Morton, Molecular markers in blood as surrogate prognostic indicators of melanoma recurrence, Cancer Res 60 (2000), 2253-2257. 


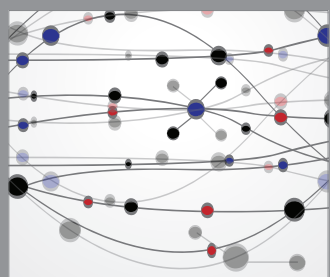

The Scientific World Journal
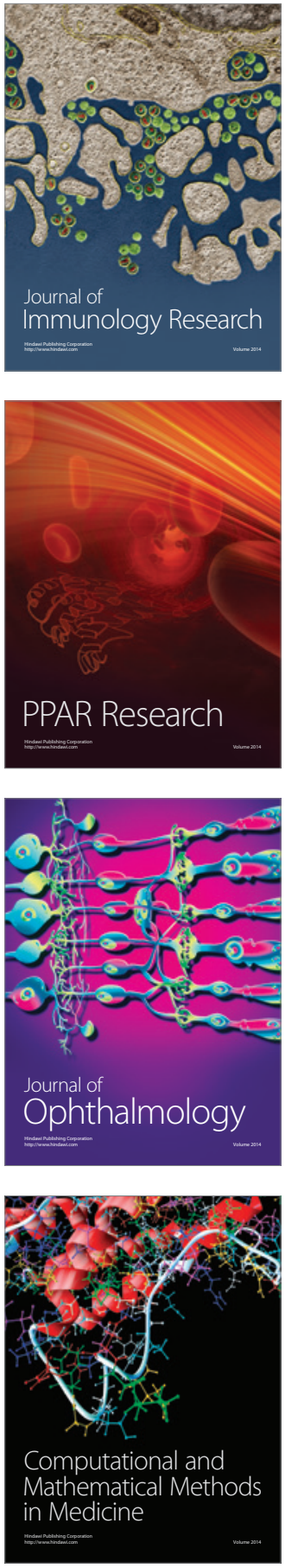

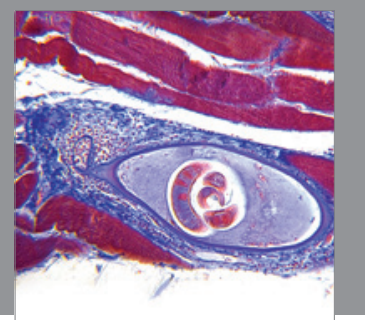

Gastroenterology

Research and Practice
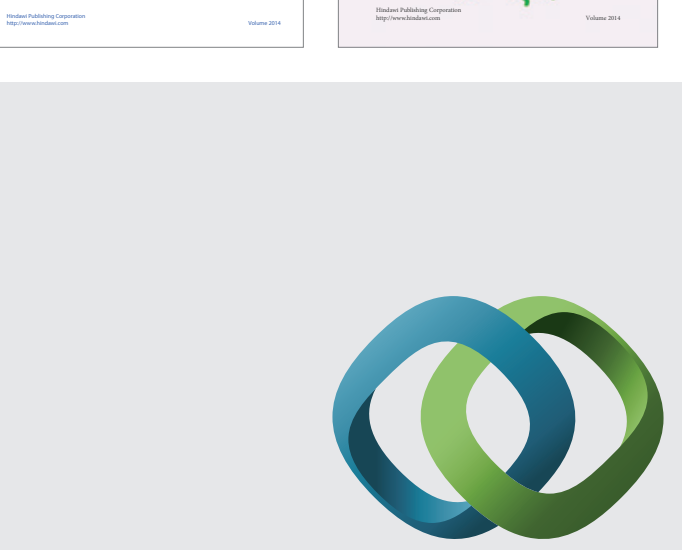

\section{Hindawi}

Submit your manuscripts at

http://www.hindawi.com
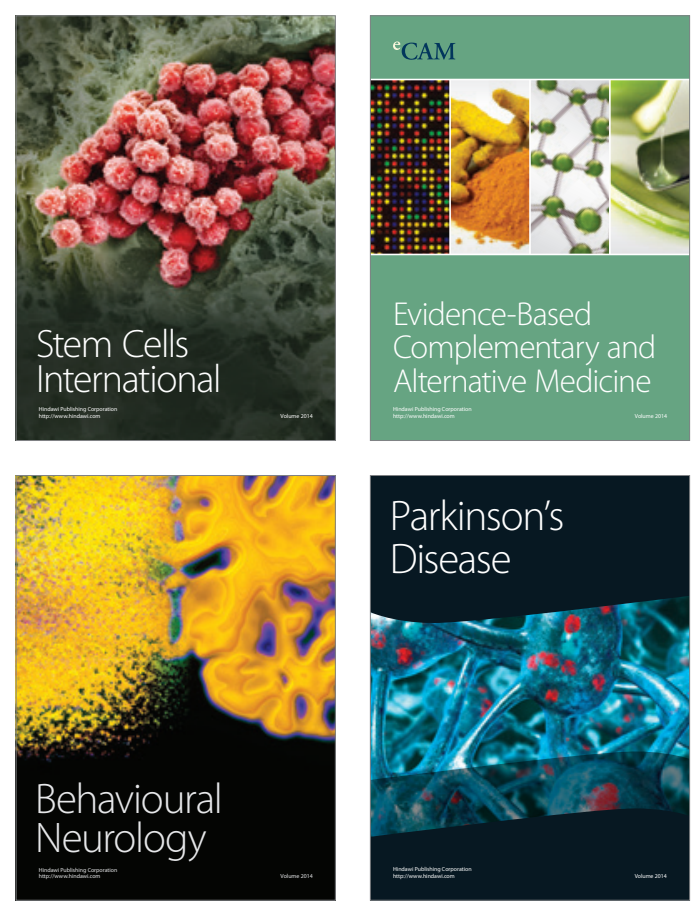

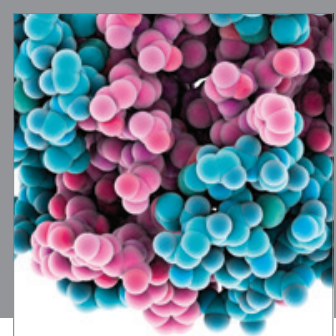

Journal of
Diabetes Research

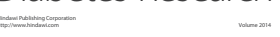

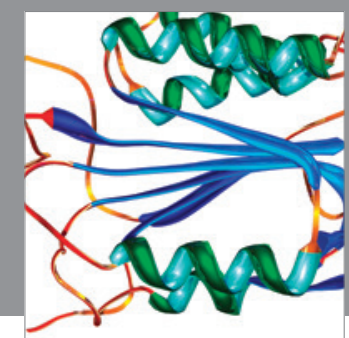

Disease Markers
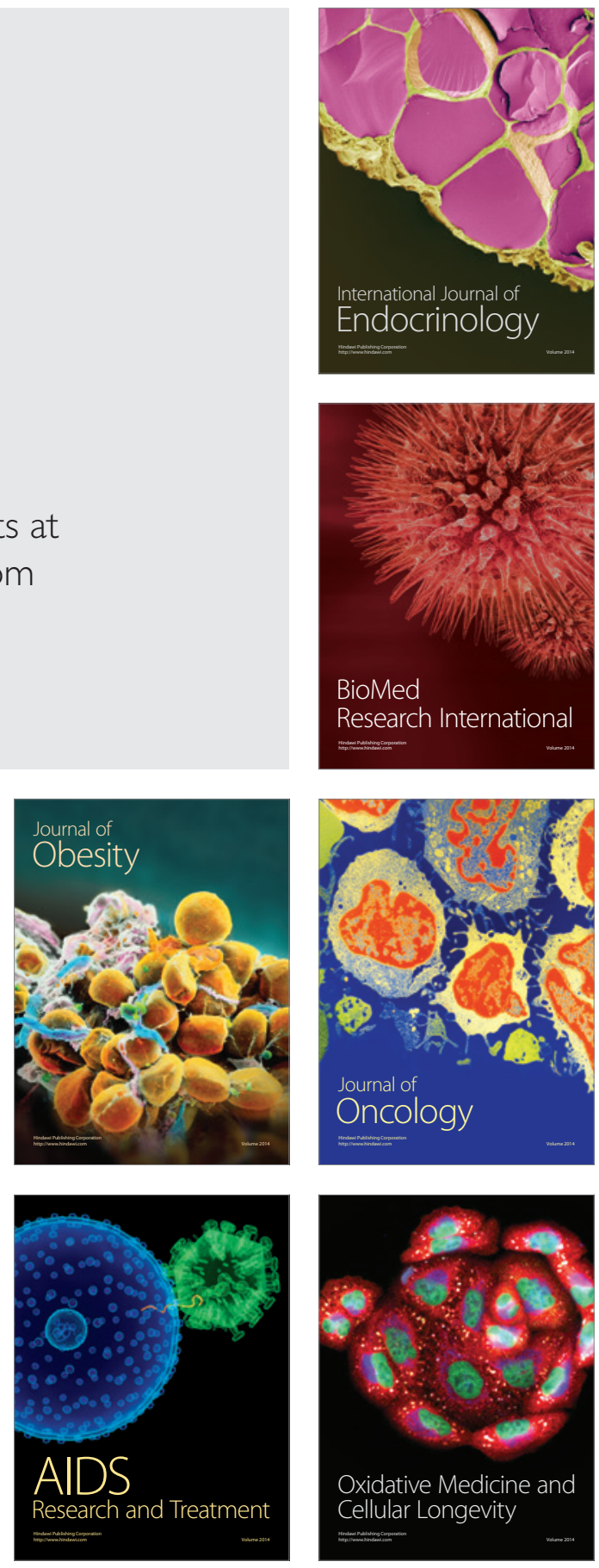